JIIA, VOLUME 6 No. 3, AGUSTUS 2018

\title{
ANALISIS PENDAPATAN DAN PEMASARAN KAKAO DI KECAMATAN BULOK KABUPATEN TANGGAMUS
}

(Analysis of Cocoa Income and Marketing in Bulok Subdistrict of Tanggamus Regency)

Stella Ayu Anggraeni, Fembriarti Erry Prasmatiwi, Suriaty Situmorang

Jurusan Agribisnis, Fakultas Pertanian, Universitas Lampung, Jl. Prof. Dr. Soemantri Brodjonegoro No. 1 Bandar Lampung 35145, Telp 085279782788, email: stellaayuanggraeni@ gmail.com

\begin{abstract}
This research aimed to analyze the income of cocoa farming and cocoa marketing efficiency in Bulok Subdistrict of Tanggamus Regency. This research was conducted purposively in Suka Agung and Napal Village on April to May 2017. The farmer respondents were chosen randomly and the marketing agency respondents were chosen from marketing agency which was directly involved in cocoa marketing at the research area. The analysis used was quantitative descriptive method. The result showed that the income of cocoa farming of cash cost was Rp23,502,689.07 per year and the income of cocoa farming of total cost was Rp16,365,572.38 per year. The cocoa marketing system in Bulok Subdistrict of Tanggamus Regency was inefficient, because some marketing channel (50\%) had producer share less than 60 percent, the value of total marketing margins was still high (36.08\%), with uneven ratio of profit margin.
\end{abstract}

Key words: cocoa, farming, income, marketing

\section{PENDAHULUAN}

Kakao merupakan salah satu komoditas perkebunan unggulan Indonesia. Kakao hasil produksi Indonesia tidak hanya digunakan untuk mencukupi kebutuhan dalam negeri namun juga untuk memenuhi kebutuhan kakao dunia. Menurut Pusat Data dan Sistem Informasi Pertanian (2016), Indonesia merupakan eksportir biji kakao terbesar ke-tiga di dunia setelah Pantai Gading, dan Ghana, serta merupakan negara nomor satu pengekspor biji kakao terbesar di wilayah Asia Tenggara.

Provinsi Lampung merupakan salah satu sentra produksi kakao di Indonesia. Menurut Dinas Pekebunan Provinsi Lampung (2016) jenis kepemilikan lahan perkebunan kakao yang ada di Provinsi Lampung terdiri dari perkebunan rakyat dan perkebunan besar swasta. Luas perkebunan kakao rakyat mencapai 94,89 persen dari total luas perkebunan kakao yang ada di Lampung dengan sumbangan produksi kakao perkebunan rakyat mencapai 94,38 persen dari total produksi kakao di Lampung. Hal tersebut menunjukkan bahwa perkebunan kakao yang ada di Provinsi Lampung didominasi oleh perkebunan rakyat.

Berdasarkan data dari Dinas Perkebunan Provinsi Lampung (2016), jumlah petani perkebunan rakyat untuk semua jenis komoditas perkebunan yang ada di Provinsi Lampung adalah sebanyak 877.056 orang kepala keluarga. Sebanyak 10,25 persen dari total petani pekebun tersebut adalah petani kakao. Jumlah keseluruhan petani kakao perkebunan rakyat di Provinsi Lampung mencapai 116.259 orang kepala keluarga. Perkebunan kakao di Provinsi Lampung tersebar di seluruh kabupaten.

Kabupaten Tanggamus merupakan salah satu sentra produksi kakao di Provinsi Lampung, yang menempati urutan pertama dengan lahan terluas di Provinsi Lampung. Perkebunan kakao tersebar di seluruh kecamatan yang ada dan Kecamatan Bulok merupakan salah satu kecamatan dimana mayoritas penduduknya melakukan usahatani kakao, meskipun bukan yang tertinggi dalam hal luas lahan dan produksinya. Lebih tepatnya, Kecamatan Bulok merupakan kecamatan dengan luas lahan dan produksi terbesar ke-empat di Kabupaten Tanggamus (BPS Kabupaten Tanggamus 2016).

Usahatani kakao yang dilakukan oleh petani di Kecamatan Bulok Kabupaten Tanggamus tidak selalu memberikan banyak keuntungan, dari hasil pengamatan di lapangan, tanaman kakao mudah terserang hama dan penyakit yang merugikan para petani, karena mampu menurunkan hasil produksi. Hal tersebut berpengaruh terhadap kualitas biji kakao yang dihasilkan dan juga harga jualnya. Selain itu, penanganan pasca panen kakao juga sangat mempengaruhi harga jual kakao. 
Penanganan pasca panen yang dilakukan oleh petani di Kecamatan Bulok berupa kegiatan penjemuran dengan mengandalkan sinar matahari sebagai sumber panas untuk proses pengeringan biji kakao dan penurunan kadar airnya. Lamanya proses penjemuran menjadi hal yang penting untuk diperhatikan guna menghasilkan biji kakao dengan tingkat kadar air yang sesuai. Namun tidak semua petani yang ada di Kecamatan Bulok memperhatikan hal tersebut. Kebanyakan petani di Kecamatan Bulok melakukan penjemuran biji kakao dengan lama penjemuran yang tidak pasti, ada yang menjemur dengan lama penjemuran satu hari, dua hari, atau lebih. Proses pengeringan biji kakao seperti itu biasa disebut oleh para petani dengan kakao kering asalan.

Harga jual kakao kering asalan inilah yang mengakibatkan tidak samanya harga jual yang diterima oleh petani. Selain itu harga jual kakao juga dipengaruhi oleh panjang pendeknya rantai pemasaran. Semakin panjang rantai pemasaran, akan mengakibatkan bagian harga yang diterima oleh petani semakin rendah.

Kecamatan Bulok memiliki unit pembelian kakao skala besar dan sudah berorientasi ekspor, sehingga banyak kakao dari luar kecamatan, bahkan luar kabupaten, yang dijual ke unit pembelian kakao tersebut. Unit pembelian yang ada diharapkan mampu menunjang kegiatan pemasaran kakao menjadi lebih mudah dan menguntungkan. Namun kenyataannya, banyak petani yang lebih memilih menjual kakao kepada tengkulak atau pedagang pengumpul dibandingkan menjualnya langsung kepada unit pembelian tersebut. Hal ini menyebabkan harga kakao yang diterima petani rendah.

Harga kakao dan jumlah produksi kakao menentukan besar kecilnya pendapatan yang akan diperoleh petani. Oleh karena itu penelitian tentang pendapatan dan pemasaran kakao di Kecamatan Bulok Kabupaten Tanggamus perlu dilakukan. Tujuan dari penelitian ini adalah untuk menganalisis pendapatan usahatani kakao dan menganalisis efisiensi pemasaran kakao di Kecamatan Bulok Kabupaten Tanggamus.

\section{METODE PENELITIAN}

Penelitian ini menggunakan metode survai. Menurut Sugiyono (2013), metode survai adalah metode untuk mengambil suatu generalisasi dari pengamatan yang tidak mendalam. Pada metode survai diambil beberapa sampel dari populasi yang dianggap dapat mewakili populasi tersebut. Penelitian dilakukan di Desa Suka Agung dan Desa Napal Kecamatan Bulok Kabupaten Tanggamus. Lokasi penelitian ditentukan secara sengaja dengan pertimbangan bahwa Desa Suka Agung dan Desa Napal memiliki luas lahan kering yang digunakan untuk perkebunan rakyat tertinggi. Pengumpulan data dilakukan pada Bulan April hingga Mei 2017.

Sampel dalam penelitian ini dibedakan menjadi dua, yaitu sampel petani dan pedagang. Populasi petani kakao di Desa Suka Agung adalah 665 orang dan di Desa Napal adalah 387 orang. Apabila dijumlahkan, maka populasi petani kakao dua desa tersebut adalah 1.052 orang. Jumlah sampel petani pada penelitian ini mengacu pada penentuan besarnya sampel menurut Yount, yaitu lima persen dari total populasi (Arikunto 2006), sehingga diperoleh jumlah sampel sebanyak 53 petani kakao. Penentuan besarnya sampel menurut Yount disajikan pada Tabel 1. Dari jumlah sampel yang didapat, maka ditentukan alokasi proporsi sampel tiap desa dengan rumus:

$\mathrm{na}=\frac{\mathrm{Na} \times \mathrm{nab}}{\mathrm{Nab}} \ldots \ldots \ldots \ldots \ldots \ldots \ldots \ldots \ldots$

Keterangan:

na $=$ Jumlah sampel per desa

nab $=$ Jumlah sampel keseluruhan

$\mathrm{Na}=$ Jumlah petani per desa

$\mathrm{Nab}=$ Jumlah populasi petani

sehingga jumlah sampel petani per desa yaitu :

na Desa Suka Agung $=\frac{665 \times 53}{1.052}=33,5 \approx 34$

na Desa Napal $\quad=\frac{387 \times 53}{1.052}=19,4 \approx 19$

Responden kemudian dipilih secara acak sederhana (simple random sampling) dengan pertimbangan bahwa populasi dianggap homogen, sedangkan sampel pedagang perantara dalam pemasaran kakao dipilih dari para lembaga pemasaran yang terlibat langsung dalam proses pemasaran kakao di lokasi penelitian. Cara pengambilan sampel dilakukan dengan mengikuti alur pemasaran kakao di Kecamatan Bulok. 
Tabel 1. Penentuan besarnya sampel menurut Yount

\begin{tabular}{clc}
\hline No. & \multicolumn{1}{c}{ Besar Populasi } & $\begin{array}{c}\text { Besar Sampel } \\
\text { (persen populasi) }\end{array}$ \\
\hline 1. & $0-100$ & 100 \\
2. & $101-1.000$ & 10 \\
3. & $1.001-5.000$ & 5 \\
4. & $5.001-10.000$ & 3 \\
5. & $>10.000$ & 1 \\
\hline \multicolumn{2}{l}{ Sumber : Arikunto (2006) }
\end{tabular}

Data yang digunakan dalam penelitian ini adalah data primer dan data sekunder. Data primer adalah data yang diperoleh peneliti secara langsung dari wawancara dengan responden penelitian, yakni petani kakao dan pedagang yang terlibat dalam pemasaran kakao menggunakan kuesioner yang telah disediakan. Data sekunder adalah data yang diperoleh dari sumber yang sudah ada, seperti dari Dinas Perkebunan Provinsi Lampung, Badan Pusat Statistik Provinsi Lampung, Badan Pusat Statistik Kabupaten Tanggamus, BP3K Kecamatan Bulok, dan pustaka lainnya yang terkait dan relevan dengan penelitian ini. Metode analisis yang digunakan adalah analisis deskriptif kuantitatif. Analisis deskriptif kuantitatif digunakan untuk mengetahui besarnya pendapatan usahatani kakao dan efisiensi pemasaran kakao.

Pendapatan usahatani kakao diperoleh dengan menghitung selisih antara penerimaan dengan biaya produksi yang dikeluarkan dalam proses usahatani. Untuk mengetahui pendapatan petani digunakan rumus Soekartawi (1995) :

$$
\mathrm{Pd}=\mathrm{TR}-\mathrm{TC}=\mathrm{Y} . \mathrm{Py}-\Sigma \mathrm{Xi} . \mathrm{Pxi}
$$

Keterangan :

$\mathrm{Pd}=$ Pendapatan usahatani $(\mathrm{Rp})$

$\mathrm{TR}=$ Total penerimaan $(\mathrm{Rp})$

$\mathrm{TC}=$ Total biaya $(\mathrm{Rp})$

$\mathrm{Y}=$ Jumlah produksi $(\mathrm{kg})$

Py $=$ Harga produksi $(\mathrm{Rp})$

$\mathrm{Xi}=$ Faktor produksi $(\mathrm{i}=1,2,3, \ldots, \mathrm{n})$

Pxi $=$ Harga faktor produksi $(\mathrm{Rp})$

Analisis yang digunakan untuk mengetahui efisiensi pemasaran dalam penelitian ini menggunakan konsep analisis struktur, perilaku dan keragaan pasar. Struktur pasar mengacu pada dimensi fisik yang menyangkut definisi industri dan pasar, jumlah perusahaan atau produsen di pasar, distribusi perusahaan atau produsen dalam berbagai ukuran dan konsentrasi, deskripsi produk, dan diferensiasi produk, serta rintangan masuk pasar dan sebagainya. Perilaku pasar mengacu pada perilaku perusahaan atau lembaga pemasaran pada struktur pasar tertentu dan tipe keputusan yang diambil dalam berbagai struktur pasar. Keragaan Pasar mengacu pada pengaruh nyata struktur dan perilaku yang diukur dalam beberapa variabel, yaitu harga, biaya, dan volume output. Keragaan pasar melihat sejauh mana pengaruh riil struktur dan perilaku pasar yang berkenaan dengan harga, biaya, dan volume produksi (Hasyim 2012). Keragaan pasar dalam penelitian ini dilihat dari saluran pemasaran, pangsa produsen, margin pemasaran dan RPM (Ratio Profit Margin).

\section{HASIL DAN PEMBAHASAN}

\section{Profil Petani}

Petani kakao memiliki rata-rata umur 46 tahun, dengan tingkat pendidikan petani mayoritas adalah tamat SD $(35,85 \%)$, sehingga dapat dikategorikan cukup rendah. Jumlah tanggungan keluarga petani sebanyak $2-3$ orang $(54,72 \%)$. Untuk memenuhi kebutuhan keluarga, petani memiliki pekerjaan utama sebagai petani kakao dan pekerjaan sampingan, yaitu seperti usaha ternak, berdagang, buruh tani, dan buruh non pertanian.

Pengalaman usahatani yang dimiliki oleh petani dalam melakukan usahatani kakao rata-rata 15,26 tahun, dengan mayoritas berada pada kisaran 2-15 tahun $(58,49 \%)$. Luas lahan yang dimiliki petani mulai dari 0,25 hektar sampai 4 hektar, dengan rata-rata luas lahan adalah 1,13 hektar. Mayoritas petani memiliki luas lahan $0,25-1,50$ hektar $(86,80$ $\%$ ) dengan status lahan milik sendiri. Jenis kakao yang diusahakan oleh petani sebagian besar adalah jenis kakao lokal $(94,34 \%)$ sedangkan sisanya mengusahakan jenis kakao F1 Jember, Sumatera, dan Jambangan. Umur tanaman kakao berada pada kisaran 5-25 tahun, dengan rata-rata 14,30 tahun. Mayoritas tanaman kakao berada pada kisaran umur 5-11 tahun $(47,17 \%)$ dengan rata-rata jumlah pohon adalah 687 pohon per hektar.

\section{Profil Pedagang}

Lembaga perantara yang dimaksud dalam penelitian ini adalah pedagang yang terlibat dalam proses pemasaran kakao di Kecamata Bulok, yaitu tengkulak, pedagang pengumpul, dan pedagang besar. Terdapat 14 pedagang atau lembaga perantara pemasaran kakao, yang terdiri dari tiga orang tengkulak, sembilan orang pedagang pengumpul dan dua orang pedagang besar. 
Umur pedagang perantara dalam proses pemasaran berkisar antara 38-62 tahun, dengan rata-rata umur adalah 51 tahun. Mayoritas pedagang perantara berada pada kisaran umur 47-55 tahun (50\%).

Tingkat pendidikan mayoritas adalah tamat SD, dan pengalaman berdagang kakao rata-rata adalah 16 tahun.

\section{Pengelolaan Usahatani Kakao}

Tanaman kakao yang diusahakan oleh petani berkisar 5-25 tahun. Tanaman yang berumur di atas 15 tahun merupakan tanaman yang diperoleh petani dari bibit bantuan Dinas Pertanian Kabupaten Tanggamus atau dari bibit hasil membeli di tempat pembibitan, sedangkan tanaman kakao yang berumur muda sudah ada yang diperoleh dari bibit hasil pembibitan sendiri.

Luas lahan yang diusahakan oleh petani berkisar antara 0,25-4 hektar dengan rata-rata luas lahan adalah 1,13 hektar. Rata-rata jumlah pohon kakao yang ditanam oleh petani dalam satu hektar adalah 687 pohon. Biasanya di sela-sela tanaman kakao atau di pinggir lahan dimanfaatkan oleh petani untuk ditanami tanaman tumpang sari, seperti pisang, kopi, lada, cengkeh, jengkol, kelapa, jati, kapulaga, dan pepaya. Mayoritas petani $(75,47$ persen) menanam pisang sebagai tanaman tumpang sari kakao, karena tanaman pisang dapat dipanen setiap bulan. Hal ini tentunya sangat pembantu petani, karena kakao sebagai tanaman utama tidak dapat di panen setiap bulan, seperti pada saat masa pembungaan.

Pemeliharaan yang dilakukan oleh petani adalah pemupukan, pengendalian hama dan penyakit tanaman, pemangkasan dan penyiangan. Pemupukan tanaman kakao dilakukan 1-2 kali dalam satu tahun. Jenis pupuk yang digunakan meliputi pupuk Urea, NPK Phoska, SP36, kandang, dan NPK Mutiara. Pemberantasan hama dan penyakit tanaman menggunakan pestisida seperti Marshal, Gandasil Buah, Sipermetrin, Astertin, Sidolaris, Sidabas, Round Up, dan Gramaxone. Frekuensi penyemprotan tergantung pada intensitas hama dan penyakit yang menyerang. Kegiatan pemeliharaan lainnya, yaitu pemangkasan dan penyiangan. Pemangkasan yang dilakukan meliputi pemangkasan tunas air, pemangkasan beberapa bagian tanaman yang terkena penyakit, dan bagian tanaman yang sudah tidak produktif, sedangkan penyiangan adalah kegiatan pembersihan gulma yang berada di selasela tanaman kakao.
Panen buah kakao tebagi mejadi dua, yaitu panen raya dan panen selang. Panen raya merupakan pemanenan kakao dalam jumlah besar dan puncaknya terjadi pada bulan April dan Mei, tetapi ada pula yang sampai pada bulan Juni. Selanjutnya panen raya kedua terjadi pada bulan Oktober dan November. Namun, saat ini, hanya terjadi satu kali panen raya. Hal ini dipengaruhi oleh berbagai faktor, salah satunya adalah cuaca.

Kegiatan pascapanen yang dilakukan oleh petani meliputi pemecahan kulit buah kakao dan penjemurah biji kakao. Penjemuran biji kakao dilakukan dengan mengandalkan panas dari sinar matahari. Penjemuran kakao dilakukan oleh petani di halaman rumahnya masing masing, menggunakan alas jemur berupa plastik terpal atau dengan lantai semen. Lamanya proses penjemuran yang dilakukan oleh petani berbeda-beda.

\section{Pendapatan Usahatani Kakao}

Mayoritas usahatani kakao yang dilakukan oleh petani di Kecamatan Bulok Kabupaten Tanggamus diusahakan secara tumpang sari dengan tanaman lain, sehingga jenis produksi yang dihasilkan dari usahatani kakao juga beragam, yaitu kakao dan hasil produksi dari tanaman lainnya yang merupakan tanaman tumpang sari kakao. Rata-rata jumlah produksi kakao adalah 1.117,15 kilogram per tahun.

Biaya usahatani kakao dalam penelitian ini dibedakan menjadi biaya tunai dan biaya diperhitungkan. Biaya tunai adalah biaya yang secara tunai atau langsung dikeluarkan petani dalam kegiatan usahataninya, sedangkan biaya diperhitungkan adalah biaya yang tidak dikeluarkan oleh petani tetapi diperhitungkan dalam kegiatan usahatani. Biaya tunai yang dikeluarkan oleh petani meliputi biaya pupuk, biaya pestisida, biaya transportasi, biaya pajak, biaya tenaga kerja luar keluarga, biaya penjualan kakao, biaya yang digunakan untuk produksi tanaman tumpang sari, dan biaya untuk penjualan tanaman tumpang sari. Biaya diperhitungkan terdiri dari biaya tenaga kerja dalam keluarga, biaya penyusutan alat pertanian, serta biaya sewa lahan. Total biaya usahatani kakao adalah Rp11.100.047,91 per tahun.

Penerimaan usahatani kakao dihitung berdasarkan jumlah penerimaan yang diperoleh dari hasil produksi kakao sebagai tanaman utama ditambah dengan jumlah penerimaan yang diperoleh dari 
hasil produksi tanaman tumpang sarinya. Penerimaan yang diperoleh dari produksi kakao adalah Rp22.122.140,57 per tahun dan penerimaan yang diperoleh dari produksi tanaman tumpang sarinya adalah Rp5.343.497,71 per tahun, sehingga total penerimaan usahatani kakao adalah Rp27.465.620,28 per tahun. Secara lebih rinci penerimaan, biaya, pendapatan, dan $\mathrm{R} / \mathrm{C}$ rasio usahatani kakao di Kecamatan Bulok disajikan pada Tabel 2.

Tabel 2. Penerimaan, biaya, pendapatan, dan $\mathrm{R} / \mathrm{C}$ rasio usahatani kakao per satu hektar di Kecamatan Bulok, 2017

\begin{tabular}{|c|c|c|c|c|}
\hline No & Uraian & $\begin{array}{l}\text { Harga } \\
(\mathrm{Rp})\end{array}$ & Jumlah & $\begin{array}{l}\text { Nilai } \\
(\mathrm{Rp})\end{array}$ \\
\hline \multicolumn{5}{|c|}{1 Penerimaan } \\
\hline & Kakao (kg) & $19.956,73$ & $1.117,15$ & $22.122 .140,57$ \\
\hline & Tan. tumpang sari $(\mathrm{kg})$ & & & $5.343 .479,71$ \\
\hline & Total penerimaan $(\mathrm{Rp})$ & & & $27.465 .620,28$ \\
\hline \multirow{3}{*}{\multicolumn{5}{|c|}{$\begin{array}{l}2 \text { Biaya usahata } \\
\text { a. Biaya tunai } \\
\text { Pupuk }\end{array}$}} \\
\hline & & & & \\
\hline & & & & \\
\hline & Urea $(\mathrm{kg})$ & $1.931,11$ & 145,27 & $271.831,69$ \\
\hline & NPK (kg) & $2.768,29$ & 186,17 & $509.433,96$ \\
\hline & SP36 (kg) & $2.708,33$ & 79,31 & $212.556,35$ \\
\hline & Kandang (kg) & 150,00 & 651,19 & $122.725,00$ \\
\hline & NPK Mutiara (kg) & $12.500,00$ & 5,18 & $56.770,75$ \\
\hline \multicolumn{5}{|c|}{ Pestisida } \\
\hline & Marshal (liter) & $140.000,00$ & 0,07 & $10.519,29$ \\
\hline & Gandasil Buah (kg) & $68.333,33$ & 0,13 & $8.348,64$ \\
\hline & Sipermetrin (liter) & $120.000,00$ & 0,09 & $10.519,29$ \\
\hline & Astertin (liter) & $243.500,00$ & 0,09 & $20.531,81$ \\
\hline & Sidolaris (liter) & $41.500,00$ & 0,79 & $35.773,92$ \\
\hline & Sidabas (liter) & $40.000,00$ & 0,08 & $3.339,46$ \\
\hline & Round Up (liter) & $60.000,00$ & 0,10 & $6.261,48$ \\
\hline & Gramaxone (liter) & $60.000,00$ & 0,07 & $4.007,35$ \\
\hline & Transportasi (Rp) & & & $77.224,91$ \\
\hline & Pajak (Rp) & & & $2.838,54$ \\
\hline & TKLK (HOK) & $53.867,92$ & 30,16 & $1.677 .492,07$ \\
\hline & Penjualan kakao (Rp) & & & $18.998,16$ \\
\hline \multicolumn{5}{|c|}{ Usahatani tan. } \\
\hline & tumpang sari (Rp) & & & $443.980,63$ \\
\hline \multicolumn{5}{|c|}{ Penjualan produksi } \\
\hline & tan. tumpang sari (Rp) & & & $469.777,93$ \\
\hline & Total biaya tunai & & & $3.962 .931,21$ \\
\hline \multirow{2}{*}{\multicolumn{5}{|c|}{$\begin{array}{l}\text { b. Biaya } \\
\text { diperhitungkan }\end{array}$}} \\
\hline & & & & \\
\hline & TKDK (HOK) & $53.867,92$ & 105,76 & $5.651 .861,75$ \\
\hline & Penyusutan alat (Rp) & & & $170.344,28$ \\
\hline & Sewa lahan $(\mathrm{Rp})$ & & & $1.314 .910,67$ \\
\hline \multicolumn{5}{|c|}{ Total biaya } \\
\hline & diperhitungkan (Rp) & & & 7.137.116,70 \\
\hline & Total biaya (Rp) & & & 11.100.047,91 \\
\hline \multicolumn{5}{|c|}{3 Pendapatan Usahatani } \\
\hline & Pend. atas biaya tunai & & & $23.502 .689,07$ \\
\hline \multicolumn{2}{|r|}{ Pend. atas biaya total } & & & $16.365 .572,38$ \\
\hline \multicolumn{5}{|c|}{$\mathrm{R} / \mathrm{C}$ rasio atas b. tuna } \\
\hline & $\mathrm{R} / \mathrm{C}$ rasio atas b. total & & & 2,47 \\
\hline
\end{tabular}

Pendapatan dalam usahatani kakao dibedakan menjadi dua, yaitu pendapatan usahatani atas biaya tunai, dan pendapatan usahatani atas biaya total. Berdasarkan Tabel 2 dapat diketahui bahwa pendapatan usahatani kakao atas biaya tunai dalah Rp23.502.689,07 per tahun, sedangkan pendapatan usahatani atas biaya total adalah $\mathrm{Rp} 16.365 .572,38$ per tahun.

Perhitungan $\mathrm{R} / \mathrm{C}$ rasio dilakukan untuk mengetahui apakah usahatani kakao yang dilakukan oleh petani menguntungkan atau tidak. Berdasarkan data pada Tabel 2 dapat diketahui bahwa nilai $\mathrm{R} / \mathrm{C}$ rasio lebih besar dari satu, yang berarti bahwa usahatani kakao di Kecamatan Bulok Kabupaten Tanggamus menguntungkan. Hasil penelitian ini sesuai dengan hasil penelitian Pasaribu, Prasmatiwi, dan Murniati (2016) tentang analisis kelayakan finansial usahatani kakao di Kecamatan Bulok Kabupaten Tanggamus, yang menyatakan bahwa usahatani kakao dengan pola tanam tumpang sari layak untuk diusahakan. Selain itu, Hasil penelitian ini juga sesuai dengan hasil penelitian Gusti, Haryono, dan Prasmatiwi (2013) tentang pendapatan rumah tangga petani kakao di Desa Pesawaran Indah Kecamatan Padang Cermin Kabupaten Pesawaran, yang menyatakan bahwa nilai $\mathrm{R} / \mathrm{C}$ rasio sebesar 5,18 , yang menunjukkan bahwa usahatani kakao yang dilakukan petani responden menguntungkan dan layak diusahakan.

\section{Efisiensi Pemasaran Kakao}

\section{Saluran Pemasaran}

Kakao yang dijual oleh petani di Kecamatan Bulok Kabupaten Tanggamus terlebih dahulu dijemur untuk menurunkan kadar airnya. Penjemuran kakao yang dilakukan oleh petani memanfaatkan matahari sebagai sumber panasnya. Proses penjemuran dilakukan oleh petani di halaman rumah dengan alas lantai jemur berupa terpal atau lantai semen. Lama penjemuran kakao yang dilakukan oleh petani responden berbeda-beda. Petani yang menjemur kakao satu, dua dan tiga hari akan menjual kakaonya kepada pedagang pengumpul atau tengkulak, sedangkan untuk kakao yang dijemur empat atau lima hari, petani menjualnya kepada pedagang besar, meskipun masih ada pula beberapa petani yang menjual kepada tengkulak, oleh sebab itu, saluran pemasaran kakao dibedakan berdasarkan lama penjemuran kakao yang dilakukan oleh petani. Saluran pemasaran kakao di Kecamatan Bulok disajikan pada Gambar 1. 


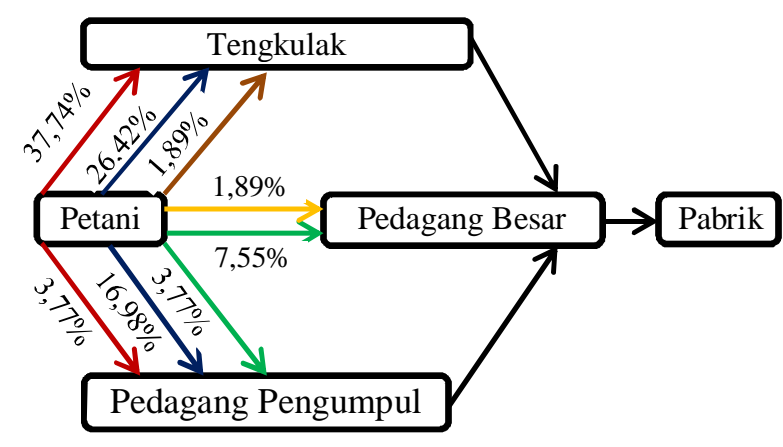

Gambar 1. Saluran pemasaran kakao di Kecamatan Bulok, 2017

Keterangan :

$\rightarrow$ Kakao dijemur satu hari

$\rightarrow$ Kakao dijemur dua hari

$\rightarrow$ Kakao dijemur tiga hari

$\rightarrow$ Kakao dijemur empat hari

$\rightarrow$ Kakao dijemur lima hari

Saluran pemasaran kakao terdiri dari delapan saluran yang dibedakan berdasarkan lima kategori lama penjemuran, yaitu :

a. Kakao dijemur satu hari, yaitu saluran :
(1) Petani $\rightarrow$ Pedagang pengumpul $\rightarrow$ Pedagang besar $\rightarrow$ Konsumen
(2) Petani $\rightarrow$ Tengkulak $\rightarrow$ Pedagang Besar $\rightarrow$ Konsumen

b. Kakao dijemur dua hari, yaitu saluran :

(3) Petani $\rightarrow$ Pedagang pengumpul $\rightarrow$ Pedagang besar $\rightarrow$ Konsumen

(4) Petani $\rightarrow$ Tengkulak $\rightarrow$ Pedagang Besar $\rightarrow$ Konsumen

c. Kakao dijemur tiga hari, yaitu saluran :

(5) Petani $\rightarrow$ Pedagang pengumpul $\rightarrow$ Pedagang besar $\rightarrow$ Konsumen

d. Kakao dijemur empat hari, yaitu saluran :

(6) Petani $\rightarrow$ Tengkulak $\rightarrow$ Pedagang besar $\rightarrow$ Konsumen

(7) Petani $\rightarrow$ Pedagang besar $\rightarrow$ Konsumen

e. Kakao dijemur lima hari, yaitu saluran :

(8) Petani $\rightarrow$ Pedagang besar $\rightarrow$ Konsumen

\section{Struktur Pasar}

Struktur pasar komoditas kakao di Kecamatan Bulok diidentifikasi dengan cara melihat jumlah lembaga pemasaran yang terlibat, sifat produk, sumber informasi dan hambatan untuk keluar maupun masuk pasar. Terdapat lima lembaga pemasaran yang terlibat dalam peoses pemasaran kakao di Kecamatan Bulok, yaitu petani, pedagang pengumpul, tengkulak, pedagang besar, dan pabrik sebagai konsumen akhir. Jumlah petani sebagai penjual kakao lebih banyak dibandingkan jumlah pembeli, sehingga struktur pasar yang terbentuk adalah struktur pasar tidak bersaing sempurna, yaitu oligopsoni. Hasil penelitian ini sesuai dengan hasil penelitian Rizal, Ali, dan Suriaty (2017) tentang kelayakan ekonomi dan pemasaran kakao di Kabupaten Lampung Selatan, yang menyatakan bahwa jumlah petani kakao secara keseluruhan lebih banyak daripada jumlah pedagang pengumpul, pedagang besar, dan eksportir, di mana semakin turun hirarki pemasaran, maka semakin sedikit jumlah lembaga pemasarannya, sehingga struktur pasar yang terbentuk adalah oligopsoni.

Pembentukan harga di tingkat petani lebih banyak ditetapkan oleh pembeli, yaitu pedagang pengumpul, tengkulak, dan pedagang besar, meskipun dalam prosesnya kegiatan tawarmenawar juga dilakukan.. Informasi mengenai harga pasar diperoleh oleh petani dari pedagang pengumpul, tengkulak, dan pedagang besar.

\section{Perilaku pasar}

Perilaku pasar merupakan pola tingkah laku yang berhubungan dengan transaksi penjualan maupun pembelian serta pembentukan harga. Pengambilan keputusan petani untuk menjual kakao kepada tengkulak, pedagang pengumpul, atau pedagang besar dipengaruhi oleh lama penjemuran kakao, kemudahan proses penjualan serta permodalan.

Mayoritas petani kakao di Kecamatan Bulok lebih memilih untuk menjual kakao kepada pedagang pengumpul atau tengkulak, meskipun di daerahnya terdapat unit pembelian kakao skala besar yang menawarkan harga beli jauh lebih tinggi. Hal ini disebabkan oleh adanya kriteria yang ditetapkan pedagang besar dalam pembelian kakao, yaitu kadar air kakao kurang dari sepuluh persen, sedangkan untuk memperoleh kadar air kurang dari sepuluh persen petani harus melakukan penjemuran kakao selama empat hari atau lebih. Penjemuran bertujuan untuk mengurangi kadar air kakao, namun seiring dengan berkurangnya kadar air kakao, maka bobot kakao juga akan semakin menurun. Hal inilah yang menyebabkan 84,91 persen petani melakukan penjemuran satu hari dan dua hari. Petani beranggapan bahwa keuntungan dari penjualan kakao yang dijemur satu hari atau dua hari tidak jauh berbeda dengan kakao yang dijemur empat hari atau lebih, apabila memperhitungkan penyusutan bobot kakao akibat proses penjemuran.

Penjualan kakao kepada pedagang pengumpul atau tengkulak juga lebih memudahkan petani, karena 
petani tidak perlu mengeluarkan biaya transportasi, sebab pembeli yang datang ke rumah petani untuk melakukan transaksi pembelian kakao. selain itu, tengkulak juga bersedia memberikan pinjaman modal kepada petani dengan syarat hasil panen kakao harus dijual kepadanya. Hal inilah yang menjadi penyebab masih banyaknya petani yang lebih memilih menjual kakaonya kepada pedagang pengumpul dan tengkulak, meskipun unit pembelian kakao skala besar berada di Kecamatan Bulok itu sendiri.

Proses pembentukan harga kakao di Kecamatan Bulok Kabupaten Tanggamus dilakukan dengan cara tawar-menawar antara pedagang dengan pembeli, namun posisi petani cenderung menjadi penerima harga, karena kurangnya informasi harga yang diketahui oleh petani. Informasi harga pasar yang berlaku diperoleh dari pedagang besar yang melakukan penjualan kakao pabrik.

\section{Producer Share, Margin Pemasaran, dan RPM}

Pangsa produsen merupakan bagian dari harga yang dibayarkan konsumen akhir yang dapat dinikmati sebagai milik produsen. Terdapat empat saluran dalam sistem pemasaran kakao di Kecamatan Bulok yang memiliki pangsa produsen lebih dari 60 persen, sedangkan empat saluran lainnya kurang dari 60 persen. Secara lebih rinci sebaran producer share, margin pemasaran, dan ratio profit margin dalam pemasaran kakao di Kecamatan Bulok Kabupaten Tanggamus disajikan pada Tabel 3.

Tabel 3. Sebaran producer share, margin pemasaran, dan ratio profit margin dalam sistem pemasaran kakao di Kecamatan Bulok, 2017

\begin{tabular}{|c|c|c|c|c|c|c|c|c|}
\hline Unsur Marjin & Saluran 1 & Saluran 2 & Saluran 3 & Saluran 4 & Saluran 5 & Saluran 6 & Saluran 7 & Saluran 8 \\
\hline \multicolumn{9}{|l|}{ 1.Petani } \\
\hline Harga Jual Jual (Rp/kg) & $15.535,67$ & $16.250,00$ & $20.154,34$ & \multirow{2}{*}{\multicolumn{2}{|c|}{$21.077,0524.571,43$}} & $29.714,29$ & $31.181,25$ & $33.914,29$ \\
\hline biaya transportasi $(\mathrm{Rp} / \mathrm{kg})$ & & & & & & & 200,00 & 200,00 \\
\hline Producer share (\%) & 42,11 & 43,10 & 54,63 & 55,91 & 65,18 & 78,82 & 82,18 & 89,43 \\
\hline \multicolumn{9}{|l|}{ 2.Pedagang pengumpul } \\
\hline Harga Beli (Rp/kg) & $15.535,67$ & & $20.154,34$ & \multicolumn{2}{|r|}{$24.571,43$} & & & \\
\hline Biaya $(\mathrm{Rp} / \mathrm{kg})$ : & 579,37 & & 667,54 & \multicolumn{2}{|r|}{235,00} & & & \\
\hline Angkut (Rp/kg) & 200,00 & & 200,00 & \multicolumn{2}{|r|}{200,00} & & & \\
\hline Tenaga kerja $(\mathrm{Rp} / \mathrm{kg})$ & 344,37 & & 432,54 & \multicolumn{2}{|r|}{0,00} & & & \\
\hline Kemas $(\mathrm{Rp} / \mathrm{kg})$ & 35,00 & & 35,00 & \multicolumn{2}{|r|}{35,00} & & & \\
\hline Marjin Pemasaran $(\mathrm{Rp} / \mathrm{kg})$ & $13.625,33$ & & $10.503,84$ & \multicolumn{2}{|r|}{$6.261,90$} & & & \\
\hline $\begin{array}{l}\text { Margin Keuntungan } \\
(\mathrm{Rp} / \mathrm{kg})\end{array}$ & $13.045,96$ & & $9.836,30$ & \multicolumn{2}{|r|}{$6.026,90$} & & & \\
\hline Rasio Profit Margin & 22,52 & & 14,74 & \multicolumn{2}{|r|}{25,65} & & & \\
\hline Harga Jual (Rp/kg) & $29.161,00$ & & $30.658,17$ & \multicolumn{2}{|r|}{$30.833,33$} & & & \\
\hline \multicolumn{9}{|l|}{ 3.Tengkulak } \\
\hline Harga Beli (Rp/kg) & & $16.250,00$ & & \multicolumn{2}{|l|}{$21.077,05$} & $29.714,29$ & & \\
\hline Biaya (Rp/kg): & & 911,48 & & \multicolumn{2}{|l|}{$1.066,86$} & 578,78 & & \\
\hline Angkut (Rp/kg) & & 200,00 & & \multicolumn{2}{|l|}{200,00} & 200,00 & & \\
\hline Tenaga kerja (Rp/kg) & & 676,48 & & \multicolumn{2}{|l|}{831,86} & 343,78 & & \\
\hline Kemas (Rp/kg) & & 35,00 & & \multicolumn{2}{|l|}{35,00} & 35,00 & & \\
\hline Marjin Pemasaran (Rp/kg) & & $14.458,33$ & & \multicolumn{2}{|l|}{$9.997,95$} & $3.035,71$ & & \\
\hline \multicolumn{7}{|l|}{$(\mathrm{Rp} / \mathrm{kg})$} & & \\
\hline Rasio Profit Margin & & 14,86 & & \multicolumn{2}{|l|}{8,37} & 4,25 & & \\
\hline Harga Jual (Rp/kg) & & $30.708,33$ & & \multicolumn{2}{|l|}{$31.075,00$} & $32.750,00$ & & \\
\hline \multicolumn{9}{|l|}{ 4.Pedagang Besar } \\
\hline Harga Beli (Rp/kg) & $29.161,00$ & $30.708,33$ & $30.658,17$ & \multicolumn{2}{|c|}{$31.075,0030.833,33$} & $32.750,00$ & $31.181,25$ & $33.914,29$ \\
\hline Biaya $(\mathrm{Rp} / \mathrm{kg})$ : & 964,31 & 965,03 & 964,31 & 965,03 & 965,03 & 965,03 & 965,03 & 965,03 \\
\hline Tenaga kerja $(\mathrm{Rp} / \mathrm{kg})$ & 111,57 & 88,67 & 111,57 & 88,67 & 88,67 & 88,67 & 88,67 & 88,67 \\
\hline Pengeringan (Rp/kg) & 186,90 & 210,53 & 186,90 & 210,53 & 210,53 & 210,53 & 210,53 & 210,53 \\
\hline Kemas $(\mathrm{Rp} / \mathrm{kg})$ & 32,50 & 32,50 & 32,50 & 32,50 & 32,50 & 32,50 & 32,50 & 32,50 \\
\hline Angkut $(\mathrm{Rp} / \mathrm{kg})$ & 583,33 & 583,33 & 583,33 & 583,33 & 583,33 & 583,33 & 583,33 & 583,33 \\
\hline Bongkar muat (Rp/kg) & 50,00 & 50,00 & 50,00 & 50,00 & 50,00 & 50,00 & 50,00 & 50,00 \\
\hline Marjin Pemasaran (Rp/kg) & $7.730,66$ & $6.991,67$ & $6.233,49$ & $6.625,00$ & $6.866,67$ & $4.950,00$ & $6.518,75$ & $3.785,71$ \\
\hline $\begin{array}{l}\text { Margin Keuntungan } \\
(\mathrm{Rp} / \mathrm{kg})\end{array}$ & $6.766,35$ & $6.026,64$ & $5.269,19$ & $5.659,97$ & $5.901,64$ & $3.984,97$ & $5.553,72$ & $2.820,69$ \\
\hline Rasio Profit Margin & 7,02 & 6,25 & 5,46 & 5,87 & 6,12 & 4,13 & 5,75 & 2,92 \\
\hline Harga Jual (Rp/kg) & $36.891,67$ & $37.700,00$ & $36.891,67$ & $37.700,003$ & $37.700,00$ & $37.700,00$ & $37.700,00$ & $37.700,00$ \\
\hline 5.Konsumen/pabrik $(\mathrm{Rp} / \mathrm{kg})$ & $36.891,67$ & $37.700,00$ & $36.891,67$ & $37.700,003$ & $37.700,00$ & $37.700,00$ & $37.700,00$ & $37.700,00$ \\
\hline
\end{tabular}


Berdasarkan Tabel 3 dapat diketahui bahwa pangsa produsen terbesar yang diterima oleh petani terdapat pada saluran delapan dengan pangsa produsen sebesar 89,43 persen. Besarnya pangsa produsen pada saluran delapan disebabkan oleh petani menjual kakaonya langsung ke pedagang besar tanpa perantara lembaga pemasaran seperti pedagang pengumpul ataupun tengkulak, sedangkan pangsa produsen terkecil yang diterima petani terdapat pada saluran satu dengan pangsa produsen sebesar 42,11 persen. Kecilnya pangsa produsen pada saluran satu disebabkan oleh petani memilih menjual kakaonya ke pedagang pengumpul daripada ke pedagang besar. Dapat diketahui juga bahwa lembaga pemasaran yang memperoleh margin keuntungan paling palingg besar untuk setiap kilogram kakao adalah pedagang pengumpul dan tengkulak, hal ini karena biaya pemasaran yang dikeluarkan oleh pedagang pengumpul atau tengkulak lebih sedikit dibandingkan dengan biaya pemasaran yang dikeluarkan oleh pedagang besar.

Total margin pemasaran merupakan selisih antara harga beli pada tingkat konsumen akhir dengan harga jual yang diterima oleh petani sebagai produsen (producer share), sehingga apabila total margin pemasaran dijumlahkan dengan producer share, nilainya adalah 100 persen. Nilai rata-rata total margin pemasaran dari delapan saluran yang ada adalah 36,08 persen. Total margin pemasaran paling tinggi terdapat pada saluran satu, yaitu 57,89 persen.

Ratio profit margin digunakan untuk mengetahui perbandingan antara biaya pemasaran terhadap keuntungan yang diperoleh masing-masing lembaga pemasaran pada setiap saluran pemasaran. Nilai ratio profit margin yang merata mampu menggambarkan efisiensi suatu pemasaran, namun dalam penelitian ini nilai ratio profit margin tidak menyebar merata, sehingga dapat dikatakan bahwa saluran pemasaran yang ada di Kecamatan Bulok Kabupaten Tanggamus dapat dikatakan belum efisien.

\section{KESIMPULAN}

Pendapatan usahatani kakao di Kecamatan Bulok Kabupaten Tanggamus atas biaya tunai adalah Rp23.502.689,07 per tahun dan pendapatan usahatani kakao atas biaya total adalah Rp16.365.572,38 per tahun. Sistem pemasaran kakao di Kecamatan Bulok Kabupaten Tanggamus belum efisien, karena beberapa saluran pemasaran (50\%) memiliki producer share kurang dari 60 persen, margin pemasaran (total margin) tinggi, yaitu 36,08 persen dengan ratio profit margin yang tidak merata.

\section{DAFTAR PUSTAKA}

Arikunto S. 2006. Prosedur Penelitian Suatu Pendekatan Praktek. Rineka Cipta. Jakarta.

BPS [Badan Pusat Statistik] Kabupaten Tanggamus. 2016. Tanggamus Dalam Angka 2016. https://tanggamuskab.bps.go.id/publi cation.html?Publikasi[tahunJudul]=2016\&Pub likasi[kataKunci]=tanggamus+dalam+angka\& yt0=Tampilkan. [18 Januari 2017].

Dinas Perkebunan Provinsi Lampung. 2016. Statistik Perkebunan Tahun 2015. Pemerintah Provinsi Lampung. Bandar Lampung.

Gusti AI, Haryono D, dan Prasmatiwi FE. 2013. Pendapatan rumah tangga petani kakao di Desa Pesawaran Indah Kecamatan Padang Cermin Kabupaten Pesawaran. JIIA, 3 (4) : 278-283. http://jurnal.fp.unila.ac.id/index. php/JIA/article/view/701/643. [9 Juli 2017].

Hasyim AI. 2012. Tataniaga Pertanian. Universitas Lampung. Bandar Lampung.

Pasaribu MC, Prasmatiwi FE, dan Murniati K. 2016. Analisis kelayakan finansial usahatani kakao di Kecamatan Bulok Kabupaten Tanggamus. JIIA, 4 (4) : 367-375. http:// jurnal.fp.unila.ac.id/index.php/JIA/article/vie w/1518/1372. [19 Desember 2017]

Pusat Data dan Sistem Informasi Pertanian. 2016. Outlook Kakao. http://epublikasi.pertanian.go. id/download/file/298-outlook-kakao-2016. [24 Februari 2017].

Rizal RK, Ali IH, dan Suriaty S. 2017. Kelayakan ekonomi dan pemasaran kakao di Kabupaten Lampung Selatan. JIIA, 5 (4): 384-391. http:// jurnal.fp.unila.ac.id/index.php/JIA/article/vie w/1668/1494. [22 Januari 2018].

Soekartawi. 1995. Analisis Usahatani. Raja Grafindo Persada. Jakarta.

Sugiyono. 2013. Metode Penelitian Pendidikan Pendekatan Kuantitatif, Kualitatif, dan $R \& D$. Alfabeta. Bandung. 